\title{
Economic, Political and Institutional Determinants of Budget Deficits Volatility: A Panel Data Analysis
}

\author{
Asma Arif ${ }^{1}$, Mujahid Hussain ${ }^{2}$
}

\begin{abstract}
:
This study has a major motivation to empirically find the fundamentals of budget deficit instability for the period 1984 to 2016 using panel data for South Asia and ASEAN countries. As main determinants the study has considered the role of institutions, governance variables like corruption, political instability, military in politics and conflicts.

The economic data is collected from international financial statistics and world development indicators. The data on political variables are collected from International Country Risk Data Guide (ICRG). Panel data models like Fixed Effect and Random Effect Model are used to test the volatility of budget deficit.

To make a comparison between results of panel data models and time series analysis this study also makes an arrangement analysing individual countries, using time series data. The results of panel data models and time series models of individual countries both confirm that corruption and political stability are important indicators of budget deficit.
\end{abstract}

To avoid high and unstable deficit attention should be diverted to improve the institutional setup of the economy.

Keywords: Pubic Policy, Macroeconomic stability, Fiscal deficit, Panel data, South Asia \& ASEAN.

JEL Codes: H5, H6, H3, H4.

\footnotetext{
${ }^{1}$ Coresponding author, School of Economics and Management, China University of Geosciences, Beijing, China, and Key Laboratory of Carrying Capacity Assessment for Resource and Environment, Ministry of Land and Resources, China, E-mail address: asma_cugb@yahoo.com

${ }^{2}$ Key Laboratory of Carrying Capacity Assessment for Resource and Environment, Ministry of Land and Resources, and School of Earth Science and Resources, China University of Geosciences, Beijing China
} 


\section{Introduction}

In recent years the degree of government budget deficits and debt became the most prominent issues in economics on which a lot of discussions are made. Instable fiscal deficits may be damaging to social welfare because past literature has widely shown that fiscal debt is negatively associated with the long run fiscal balance of the economy so future generation may suffer very easily (Alesina and Perotti, 1996; Woo, 1996; Alesina and Rodrik, 1994 and Persson and Tabellini, 1994). Central bank is deficient in independence and as inflation and budget deficit are closely related, so persistent budget deficit may also raise inflation (Fata and Mihov, 2010). A lot of efforts are required to recognize the determinants of the large public deficits although many researchers have tried but still needs more contribution in this context.

In the past budget deficits were considered only as an economic issue but beginning of political economics in 1980s gave a realization to researchers to observe this subject both from viewpoints of economic and political perspective. After the first oil crisis in 1973 many industrialized countries had been facing the problem of significant high budget deficits and interesting is the fact even in the prosperous years countries were facing problem of budget deficit when there was high growth of income whereas according to the economic theory the deficits should be low during the time when there is high economic growth.

As a result, in the times of high economic growth the magnitude of debt have been accumulated progressively, and more interesting is the fact, even countries are facing similar economic shocks, the amount of deficits and debt varying in magnitude as vary the number of country (Thalassinos et al., 2015a; 2015b; Ugurlu et al., 2014). The current economic philosophy alone may not be considered enough and satisfactory in order to explain the differences for deficits and debt levels for different countries, Therefore, political variables, such as the political stability, corruption, law and order, and conflicts may be included as variables in models in order to give possible explanations for the varying levels of deficits (Woo, 2003; Fatas and Mihov, 2010).

The developed and developing countries have a key challenge of persistently increasing budget deficits and its volatility for numerous reasons. First, huge deficit instability is a failure of fiscal policy because it becomes impossible to suggest at what time and degree of fiscal policy be implement and this leads to become decision making inefficient. Second, government spending volatility may be a consequence of the budget deficit instability and the distortions in the form of wasteful spending made by short-term methods to encounter these variations in expenditure. The excellence and competence of the government services for example health or education may also be low if government spending volatility depends on fiscal deficit volatility. Third, high budget deficit volatility may also be a reason for capital loss in the form of short term investment projects. High deficit volatility may 
also be a reason for high volatility of interest rates which may directly affect investment projects because it signifies a monetary load for investments. Chen et al. (2016) has shown that there must be an optimal level of public investment and government debt. According to this study after a maximum level there will be no effect of government debt and investment effect on economic growth. Over the last three decades, models which explains public deficits and its hazards and solution to solve the hazards has extensively realized attention; however, models which explain public deficit instability is somewhat a novel subject to be discussed.

The key emphasis of the current study is to empirically examine the foundations of deficit volatility for South Asia and ASEAN countries using panel data for the period 1984 to 2016 . The present study is focusing on the economic political and institutional factors that cause instability in budget deficits. The current study also draws attention of the economists towards effects of trade openness and inflation on budget deficit instability. The analysis includes the impact of political instability on the budget deficit instability. The current study is focusing on the political variables like corruption, political instability, military in politics and conflicts. The countries like Pakistan, Bangladesh, India and Sri Lanka are included as south Asia countries whereas countries like Indonesia, Malaysia, Thailand, china, Philippines are included as ASEAN countries. The reason for selection is the common features of huge unstable public deficit.

\section{Literature Review}

Over the last thirty years majority of developed and developing countries are facing persistence rise of fiscal deficits. Many countries are facing a major challenge in the form of damages of high fiscal deficit and its volatility (Pontoh, 2017). The subject of budget deficit and its determinants is widely theoretically and empirically studied (Allegret et al., 2016; Boldeanu and Tache, 2016). Nevertheless, a lot of efforts still required in the area of instability of budget deficit. The current section analyses few significant studies on this subject of interest.

The topic of budget instability is very broad because the literature can be considered according to various political variables. In the recent times the description of particular political explanatory variables e.g. political stability, size of government, fragmentation of government, type of budgetary procedures, negotiation power of unions etc., has received substantial consideration (Roubini and Sachs, 1989; De Haan and Sturm, 1994). The budget deficit and surpluses may help to minimize spending and revenue shock if tax rate is constant over time Barro (1979) and Lucas and Stokey (1983). However, these models are unable to explain reason for the rise in oil prices following the oil crises in the 1970s. These models are also unsuccessful to provide the answer why varying levels of fiscal deficits are faced by countries experienced similar economic shocks. Alesina and Perotti (1995 and 1996b) discuss that it is not possible to understand the issue of budget deficit instability without 
inclusion of the perspective of political and institutional variables because economic theory alone is unsuccessful to resolve this issue (Duguleana and Duguleana, 2016).

The association of political variables and fiscal response found in Person (2001) and Person and Tabellin (2001). The evidence is also found for low anti cyclical fiscal policy in electoral years in Hallerberg and Strauch (2002) and Sorensen et al. (2001). Few studies shown that the government with the pro-cyclical polices has instable output Lane (2003). Strict budgetary constraint has lower fiscal policy volatility Fatas and Mihov (2003 and 2006). In developing countries pro-cyclical fiscal policy may explain higher corruption level Alesina and Tabellini (2008).

Discretionary fiscal policy is negatively associated with Government size and income Afonso et al. (2008). According to previous works debt is the consequence of a fight between different groups of a population who try to take undue possession of wealth and capital. The debt is a consequence of a group who take advantage of their temporary powers of government. Debt may be used as a tool to redistribute incomes to future generations Cukierman and Meltzer (1989) and Song et al. (2014). Few studies discuss that the accumulation of debt bound future governments to choose their own choices Persson and Svensson (1989), Alesina and Tabellini (1990), and Tabellini and Alesina (1990). Natvik (2013) also provide evidence for the effect of political system on public savings and investment. Mainly related the studies of Tabellini and Alesina (1990), who claim that turnover rate stimulates excess deficits, and Glazer (1989), who claims that expected turn over motivates excess investment as incumbents attempt to constrain their successors.

Governments determine both debt and future entitlements Bouton et al. (2017) while Alesina and Drazen (1989) highlight that political fragmentation is a reason of high cost and delayed fiscal implementation of rules. Tabellini and Alesina (1990) show that parties have excessive spending if they risk losing the elections. Lizzeri (1999) also describes that competition of political party results in fiscal deficit. Azzimonti et al. (2015) have given a recent analysis of legal methods to handle unnecessary deficits constructed on the dynamic judicial bargaining model in Battaglini and Coate (2008). Azzimonti et al. (2015) claim that short run costs and long run benefits are associated with balanced budget rule and it may offset costs of fiscal deficit. According to economists remarkably high fiscal deficits are permissible only if are supported by a parliament Supermajority. The same argument is also supported by Becker et al. (2010). Gruner (2017) also paid attention on public expenditure decisions of fiscal policymakers and on political parties bargain for budget.

Persson and Tabellini (1999) found that more redistribution and larger governments are associated with majoritarian elections whereas presidential governments are less redistributive and small. In presidential systems decisions are more clear and selfgoverning (Shugart and Carey, 1992). So economic policy can be implemented without any rescheduling or interference. On the contrary the parliamentary system 
is opposite to this because it depends on the electoral laws. Alesina and Perotti (1995) and Persson and Tabellini(1997) discover that very few occurrences of large fiscal deficit are found in majoritarian and presidential electoral systems rather than with proportional governments. More occurrence of fiscal deficit are found in countries where is frequent government turnovers, and in the countries where budget process is lenient. Henisz (2004) suggests that formal checks and balance may recover economic outcomes. Woo (2003) highlights the political factors, social polarization and institutional factors. Leachman et al. (2007) demonstrates that if budget imposing institutions are strong fiscal performance may be better. In the existing literature on the relationship between income inequality and fiscal deficit limited empirical evidence is found. First econometric evidence is provided by Woo (1999) that income inequality is an important factor of fiscal deficits. Alesina and Perotti (1996a) provide evidence that political instability has positive relation with income inequality. Alesina and Rodrik (1994) and Persson and Tabellini (1994) propose that unequal income distribution with democratic country may inclined to go in favor of large redistributive spending. Woo (1999) designed a model to show that large deficits are a consequence of a greater incentives to policy makers to maintain higher spending to the sectors of their choice.

Roubini and Sachs (1989a and 1989b) gave a stress to association between fiscal deficit and the fragmentation with positive relationship. Edin and Ohlsson (1994) disclose that this conclusion provided by Roubini and Sachs (1989a and 1989b) may be a consequence of classification and measurement of the variable because it captures government fragmentation. Edin and Ohlsson (1994) claims that only minority governments has more trend to grow huge deficits. De Haan and Sturm (1994) conclude that there are no significant differences among different types governments. Edin and Ohlsson(1991) and Kontopoulos and Perotti (1999) claim that minority governments are related with greater deficits. More fiscal deficit in minority governments are just because of coordination failure as more members take part in the decision making process. Nordhaus (1975), Rogoff and Sibert (1988), Rogoff (1990) among others gave evidence that before elections all politicians follow expansionary fiscal policy. Alt and Lassen (2006) discuss that if political system is transparent politicians cannot take undue benefit and make fool of general public.

Franzese (2002) has discussed that political representatives only go for policies which gave advantage to win the following elections. Governmental cycles in election years which rely on these policies normally display greater fiscal deficits. Mink and De Haan (2005) discover that deficits incline to be higher during election years, whereas in the previous year they are not. On the other hand, Andrikopoulos et al. (2004) explore that during elections right wing government pay focus to fiscal stabilization. Alesina and Roubini (1997) found no evidence of higher deficit for left wing government. The collected works on the current issue suggests that more efforts are required to find out the sources of instability of budget deficit so it is 
better to resolve the issue if focus not only on economic variables but also to see the reality from political perspective.

\section{Methodology and Data}

The current study start analysis by application of panel data models on equation 1 presented below. The data covers up to 33 years of observation ranging from 1984 to 2016 for South Asia and ASEAN countries and the panel is unbalanced for estimation of budget deficit volatility. The current study is based on the theoretical work of Alesina and Perotti (1995) and Person and Tabellini (1997) and empirical work of Woo (2003) and Henisz (2004). These studies paid attention to the part of institutions which is important for proficient economic activity.

The current study is focusing not only on the economic variables for deficit instability but also focusing on the political determinants of budget deficit volatility. For the South Asia and ASEAN countries the study is using dynamic panel data models for the period 1984 to 2016. The empirical specification in dynamic panel data models to identify the features defining the instability of budget deficit is specified below:

$B D V_{i t}={ }_{i} \alpha B D V_{i t-1}+\beta E C O N_{i t}+\gamma I N S T_{i t}+\delta C_{i t}+v_{i}+\varepsilon_{i t}$

In the above equation volatility of budget deficit for the country $\mathrm{i}$ for the period $\mathrm{t}$ is denoted by $\mathrm{BDV}$, economic variables are denoted by $\mathrm{ECON}_{\mathrm{it}}$, political and institutional variables are denoted by INST $_{\text {it }}$, and control variables which record country special features $\mathrm{C}_{\text {it }}$.

The economic variables for the current study includes budget deficit which is used as a percentage of GDP, trade openness, per capita real GDP and inflation. The reason for the selection of real GDP per capita is to record the varying level of economic development among the countries. There are few studies which supports a negative relationship of budge deficit with real GDP per capita, and reason for this negative relationship may be the instable business cycles and inefficient economic institutions (Fatas and Mohov, 2006) and rely on discretionary fiscal policy (Rand and Tarp, 2002).

Nevertheless, the evidence of positive relationship between per capita GDP and budget deficit is also found in few studies. These studies provide the reason that high economic growth produces more resources and wealth and high economic growth provides solution of socio-economic issues in a better way (Woo, 2003). The reason for inclusion of inflation is that to capture its effect because the higher nominal interest and the level of economic uncertainty is the consequence of inflation. Economic uncertainty and volatility of budget deficit are closely related because this may leads to instability in government spending and income and this instability 
supplements by affecting the volatility of budget deficit. Therefore, it is anticipated a positive connection between budget deficit instability and higher inflation. The effect of exterior shocks is recorded by the degree of openness. In developing countries external shocks may be a reason of fiscal instability. The trade openness is calculated an exports plus imports ratio to GDP. It is anticipated that trade openness has positive association with budget deficit instability of the country. For example Wang et al. (2011), shown that trade openness is one more significant determinant of the entire value of houses sold, and this study has captured the effect by using net exports and foreign direct investment. It is expected that as the level of openness increases, the demand for real estate will increase as well, and further will increase housing. The population growth controls for the size of country effects and anticipated have a negative association to budget deficit volatility. If a country has large population it means an availability of a large group who pay taxes to government to easily finance its expenditures. This may be due to the benefits of increasing return to scales consequently the government can provide more goods and services to the public and this leads to less budget deficit instability. The explanatory variables that measure the effect of political instability are included as political stability, military in politics, corruption and external conflicts.

In the earlier literature there are numerous readings which describe the instability of budget deficit. The three separate panel data econometric methods are used by current study to fill the gap of the earlier literature. The Current study is carried out for the South Asia and ASEAN countries for the period 1984 to 2016 using the Fixed Effect and Random Effect Model. Finally to make a choice between fixed effects and random effects approach Hausman test is applied. The general econometric representation of the equation for the inclusion of theoretical variables is as follows:

$\mathrm{BDV}_{\text {it }}=\beta_{0}+\beta_{1} \mathrm{ECON}_{\text {it }}+\beta_{2} \mathrm{INST}_{\text {it }}+\beta_{3} \mathrm{C}_{\mathrm{it}}+\varepsilon_{\text {it }}$

In the above equation volatility of budget deficit is shown by BDV. In this equation $\mathrm{i}$ represent country and time period denoted by $t$, as this is a panel data study. The Economic variables are denoted by $\mathrm{ECON}_{\mathrm{it}}$. The political and institutional variables are denoted by INST $_{\text {it }}$ and finally control variables which record country special features are denoted by $\mathrm{C}_{\mathrm{it}}$.

The estimators of fixed effects are also identified as the estimator of least-squares dummy variables (LSDV). In this model each group comprises a separate dummy variable to have different constants for each group. A fixed effects model may be arrange as follows to combine effects which are particular to a country:

$\mathrm{BDV}_{\mathrm{it}}=\alpha_{\mathrm{it}}+\beta_{1} \mathrm{ECON}_{\mathrm{it}}+\beta_{2} \mathrm{INST}_{\mathrm{it}}+\beta_{3} \mathrm{C}_{\mathrm{it}}+\mathrm{u}_{\mathrm{it}}$ 
In the above equation: $\alpha_{\text {it }}$ is a country effects depending on time. There is another method to estimate the model namely random effects model. Random effect method holds the constants for each unit not as fixed but random parameter and this is the major differentiation of the two models.

\subsection{Hausman Test for Model Specification (Fixed Effects vs. Random Effects)}

The current study has used Hausman test to conclude which model is best fit for the current study whether fixed effect or random effect. If estimators are correlated with individual effect still in this situation the advantage of the use of fixed effect estimator is it is consistent. The following test statistic is used by the Hausman test:

$$
\mathrm{H}=\left(\beta^{\mathrm{FE}}-\beta^{\mathrm{RE}}\right)^{I}\left[\operatorname{Var}\left(\beta^{\mathrm{FE}}\right)-\operatorname{Var}\left(\beta^{\mathrm{RE}}\right)\right]^{-1} \ldots \ldots . \mathrm{x}^{2(\mathrm{k})}
$$

If the value of the hausman test statistic is small and the difference between the estimates is insignificant we may reject null hypothesis that random effect model is consistent and will use the fixed effect model. Contrary to this, large value of the Hausman statistics suggests that the random effects models are more suitable.

\subsection{Unit Root test and Ordinary Least Square Estimates}

To make sure the determinants of budget deficit and to make a comparison between results of panel data and time series analysis this study also makes an arrangement to study the source of budget deficit for individual country using time series data. So, to investigate the stationarity of the basic model is the first step in this regard by the usage of unit root test for four countries namely: Indonesia, Thailand, Pakistan and India. The availability of data set determines the selection of countries for the period 1984 to 2016 . We reject the null hypothesis of a unit root test if the critical value is greater than the ADF test statistic and we conclude that the series is stationary.

For a determination of unit root test the data must be first differenced, second differenced and so on until the stationarity is achieved. The Dickey Fuller approach (1979) can be considered as an appropriate and simple technique to test order of integration of the model. However, it has one drawback that it does not take into account the possibility of autocorrelation in the error process et so Dicky Fuller test may not be considered suitable. So, to reduce this problem, the Augmented DickeyFuller (ADF) test (Dickey and Fuller, 1981) simply solves this problem. This study has chosen four countries namely, Indonesia, Thailand, Pakistan and India for application Of Ordinary Least Square estimates using time series data depending upon availability of data set from 1984 to 2016.

\subsection{Data and Sample}


The current study has collected data not only for economic variables but also for the political variables using panel data from 1984 to 2016. Economic variables are obtained through international financial statistics (IFS) and world development Indicators (WDI). The source of political variables is International Country Risk Data Guide (ICRG).

The current study is using several economic variables like ratio of budget deficit to GDP, real GDP per capita, Trade openness and inflation. The reason behind to include inflation variable is to confirm the expected positive relationship between budget deficit and inflation. The ratio of trade to GDP represents trade openness and it captures the external shocks. The population growth is used as a control variable to capture the effect of country size of each country.

The political variables such as government/Political stability, external conflict, corruption, and military in politics are included to find out the impact of governmental uncertainty on budget deficit volatility. This study is using political index and it is provided by International country Risk Data Guide. Each political risk point is shown by a number assigned by this index. The maximum no of points is assigned after assessment of overall risk and the minimum no of point is zero. In this index lower total risk is shown by high risk point and higher total risk is shown by lower risk point.

\section{Empirical results and discussion}

This study has tried to explore the determinants of budget deficit volatility by application of panel data models. For the present analysis Fixed and random effect models are applied and Finally Hausman test is applied to conclude which model is best fit for the current study from the two approaches. The current study is designed for south Asia and ASEAN region for 1986 to 2016 to confirm the determinants of budget deficit.

The estimates of fixed and random effect is shown in Table 1. The equation of fixed effect model explain that all variables has expected signs but effect of military in politics and external conflicts are not significant for South Asia and ASEAN region. According to Table 1 budget deficit is positively and significantly associated with inflation and real GDP per capita. Wu et al. (2015) has shown that budget deficit has positive effect on land prices. The countries with the higher level of income have more variation in budget deficit this may be the reason of positive association between the two variables. This may be due to the developmental projects of the country as it needs more funds to finance and few studies in past has also shown the same relationship, Fatas and Mihov (2006 and 2010) and Woo (2003). The result shows that the budget volatility and population growth has a negative relationship. This may be due to the welfares effect of increasing return to scales. It is possible for the government to make available more welfare projects without affecting budget deficit if there is a large pool of tax payers as the population growth increases. 
The results of fixed effect model show that trade openness have insignificant positive association with budget deficit. In developing countries external shocks may be a reason of fiscal instability. Variations in export and import prices can affect budget deficit through exports profits or import tariffs. Positive association of trade openness with budget deficit is also shown by Agnello and Sausa (2009) and Fatas and Mahov (2010). It has been proved that effectiveness of fiscal policy depends on the efficient political setup (Alesina and Perotti, 1995) and this is proved by empirical evidence provided by different studies (Woo, 2003; Alesina and Parotti, 1996; Fatas and Mihov, 2003). In this analysis to record the impact of political and institutional variables, political stability and corruption are included and these are significantly and with budget deficit these are positively associated as shown in Table 1. Military in politics and conflicts has also expected sign but their effect is not significant. The results of random effect model illustrated that budget deficit do not bear an expected sign for inflation, corruption and military in Politics for a given set of countries. The Hausman test is presented in Table 2 to compare the results of fixed effect with the random effect. The fixed effect model is the best fit model for the current study as shown by the $\mathrm{P}$ value $=0.00$. Hausman test statistic is very small so we can conclude the difference between the estimates is insignificant and use fixed effect model and reject the null hypothesis which represents consistency of random effect model.

Table 1. Fixed Effect and random effect of South Asian and ASEAN countries

\begin{tabular}{|l|l|l|}
\hline Dependent Variable & Budget Deficit $_{\text {it }}$ & \\
\hline Variables & Fixed Effect & Random Effect \\
\hline C & $0.129234^{*}$ & $0.105746^{*}$ \\
& $(3.64)$ & $(5.76)$ \\
\hline Gdp per capita & $3.14 \mathrm{E}-09^{*}$ & $3.81 \mathrm{E}-10$ \\
& $(6.37)$ & $(1.17)$ \\
\hline Population & $-0.056845^{*}$ & $-0.024086^{*}$ \\
& $(-5.80)$ & $(-6.04)$ \\
\hline Trade openness & 0.008587 & $-0.036895^{*}$ \\
& $(0.55)$ & $(-6.81)$ \\
\hline Inflation & $0.000666^{*}$ & $-0.000125^{* *}$ \\
& $(3.19)$ & $(-1.90)$ \\
\hline Corruption & $-0.001603^{*}$ & 0.006956 \\
& $(-2.82)$ & $(2.24)$ \\
\hline Political stability & $-0.005839^{*}$ & $-0.003195^{*}$ \\
& $(-2.59)$ & $(-2.66)$ \\
\hline Military in Politics & -0.001603 & $0.006539^{*}$ \\
& $(-0.48)$ & $(3.52)$ \\
\hline External conflicts & -0.000365 & $-0.002452^{* * *}$ \\
& $(-0.17)$ & $(-1.74)$ \\
\hline R-Squared & 0.799963 & 0.182510 \\
\hline Adjusted R-Squared & 0.749159 & 0.153951 \\
\hline
\end{tabular}

Note: The * indicates significant at 1\%,** indicates significant at 5\% and $* * *$ indicates significant at $10 \%$. 
Table 2. Hausman test for model specification (Random vs. Fixed)

\begin{tabular}{|l|l|}
\hline statistic & P value \\
\hline$\chi^{2}=441.85$ & 0.000 \\
\hline
\end{tabular}

Note: P-value and $\chi^{2}$ are the probability value and Chi-square, respectively.

To make sure the determinants of budget deficit and to make a comparison between results of panel data and time series analysis this study also makes an arrangement to study the source of budget deficit for individual country using time series data. First, the current study is using unit root to test stationarity of the model for four countries namely: Indonesia, Thailand, Pakistan and India. For the time series analysis the selection of countries depends on the availability of data for 1984 to 2016 . We conclude that the series is stationary and we reject the null hypothesis of a unit root test if the ADF critical value is more than the ADF test statistic.

Second step is to apply Ordinary Least Square estimates on the data set of countries under consideration. This may help to roughly compare the panel data and time series estimates to determine the sources of budget deficit. Table 3 presents the unit root test for Indonesia. It indicates that all variables found stationary at first difference except population. Population is stationary at second difference. Table 4 presents the unit root test for Thailand. It indicates that all variables found stationary at first difference except population. Population is stationary at the initial level.

For Pakistan the unit root test is presented in Table 5. It indicates that all variables found stationary at first difference except inflation. Inflation is stationary at second difference. Table 6 presents the unit root test for India. It indicates that entire explanatory variables found stationary at first difference except budget deficit and external conflicts. Both variables are stationary at the initial level. Since all variables are stationary and there is no problem of autocorrelation so the second step is to apply OLS (Ordinary Least Square estimates) to find out the determinants of budget deficit on the equation of selective countries depending on the availability of data set from 1984 to 2016.

Table 3. Unit root test

\begin{tabular}{|c|c|c|c|}
\hline \multicolumn{4}{|l|}{ Indonesia } \\
\hline Variables & Level & First difference & Second difference \\
\hline Budget Deficit & -2.10 & $-6.47 * *$ & \\
\hline Gdp per capita & 0.17 & $-3.77 * *$ & \\
\hline Trade openness & $-3.36 * * *$ & $-8.14 * *$ & \\
\hline Inflation & -1.70 & $-4.70 * *$ & \\
\hline Population & -2.08 & -2.37 & $-3.50 * * *$ \\
\hline Corruption & 1.79 & $-3.87 * *$ & \\
\hline Political stability & -2.53 & $-6.72 * *$ & \\
\hline Military in Politics & -0.67 & $-5.7-* *$ & \\
\hline External Conflicts & $-3.24 * * *$ & $-3.97 * *$ & \\
\hline
\end{tabular}

Note: $*, * *$ and $* * *$ denotes significance at $1 \%, 5 \%$ and $10 \%$, respectively. 
Table 4. Unit root test

\begin{tabular}{|c|c|c|c|}
\hline \multicolumn{4}{|l|}{ Thailand } \\
\hline Variables & Level & First difference & Second difference \\
\hline Budget Deficit & -2.57 & $-5.83 * *$ & \\
\hline Gdp per capita & 1.21 & $-4.74 * *$ & \\
\hline Trade openness & -1.64 & $-5.96 * *$ & \\
\hline Inflation & -2.79 & $-5.05 * *$ & \\
\hline Population & $-4.09 * *$ & & \\
\hline Corruption & -1.44 & $-6.19 * *$ & \\
\hline Political stability & -1.84 & $-5.72 * *$ & \\
\hline Military in Politics & -0.62 & $-4.31 * *$ & \\
\hline External Conflicts & -0.82 & $-3.61 * *$ & \\
\hline
\end{tabular}

Note: $*, * *$ and $* * *$ denotes significance at $1 \%, 5 \%$ and $10 \%$, respectively.

Table 5. Unit root test

\begin{tabular}{|l|l|l|l|}
\hline Pakistan & Level & First difference & Second difference \\
\hline Variables & -2.00 & $-5.79^{* *}$ & \\
\hline Budget Deficit & 1.50 & $-5.17 * *$ & \\
\hline Gdp per capita & -2.98 & $-7.49^{* *}$ & \\
\hline Trade openness & 3.05 & -2.33 & $-4.37 * *$ \\
\hline Inflation & 1.53 & $-5.52^{* *}$ & \\
\hline Population & -2.51 & $-5.64 * *$ & \\
\hline Corruption & -1.48 & $-5.10^{* *}$ & \\
\hline Political stability & -1.87 & $-4.42^{* *}$ & \\
\hline Military in Politics & -2.93 & $-4.90^{* *}$ & \\
\hline External Conflicts & -2. & & \\
\hline
\end{tabular}

Note: $*, * *$ and $* * *$ denotes significance at $1 \%, 5 \%$ and $10 \%$, respectively.

\section{Table 6. Unit root test}

\begin{tabular}{|l|l|l|l|}
\hline \multicolumn{5}{|l|}{ India } & First difference & Second difference \\
\hline Variables & Level & & \\
\hline Budget Deficit & $-3.57^{* *}$ & -0.007 & $-5.14 * *$ \\
\hline Gdp per capita & 1.46 & -2.44 & $-1.91^{* * *}$ \\
\hline Trade openness & -3.09 & -2.98 & $-6.30^{* *}$ \\
\hline Inflation & 1.35 & $-4.61^{* *}$ & \\
\hline Population & 2.47 & $-4.35^{* *}$ & \\
\hline Corruption & $-3.55^{* * *}$ & $-5.59^{* *}$ & \\
\hline Political stability & -1.99 & $-4.03^{* *}$ & \\
\hline Military in Politics & -2.72 & & \\
\hline External Conflicts & $3.72^{* *}$ & & \\
\hline
\end{tabular}

Note: $*, * *$ and $* * *$ denotes significance at $1 \%, 5 \%$ and $10 \%$, respectively.

For the application of least square estimates to the equation of budget deficit this study has chosen four countries, namely, Indonesia, Thailand, Pakistan and India. The selection of countries was depended upon the availability of data set. Table 7 presents the outcome of Ordinary Least Square estimates. The outcomes show that in the case of Indonesia only real GDP per capita has a significant and positive 
association with budget deficit. It is also positive in the case of India but not significant. But in the case of Thailand and Pakistan real GDP per capita is negatively associated but it is significant only for Thailand. Inflation has a robust effect on budget deficit in the case of all four countries. The outcome shows positive association of population with budget deficit in the case of Indonesia, Thailand and India but it has non-significant effect for Thailand only. For Pakistan population growth has negative and significant relationship with budget deficit. Trade openness is a source of fiscal instability especially in Indonesia, Pakistan and India but it is not significant. It has negative and significant effect in the case of Thailand only. In current analysis to record the effect of political variables, political stability and corruption are included. Corruption is positively associated with budget deficit but it is significant only for Indonesia as shown in Table 7. Political stability is negatively and significantly associated only for Pakistan and India. The outcome of the current study indicates that budget is more stable with the higher political stability. Military in politics has also the expected sign only for Pakistan and India but their effect is significant only for India. An external conflict has the expected signs only for Thailand and it is significant as shown in Table 7.

Table 7. Ordinary Least Square estimates

\begin{tabular}{|l|l|l|l|l|}
\hline Dependent Variable & \multicolumn{4}{l|}{ Budget Deficit } \\
it & Indonesia & Thailand & Pakistan & India \\
\hline Vauntry & & & & \\
\hline $\mathrm{C}$ & $-0.19^{* *}$ & -0.09 & 0.30 & $-0.29^{* *}$ \\
& $(-2.23)$ & $(-1.07)$ & $(1.26)$ & $(2.06)$ \\
\hline Gdp per capita & $0.000000003^{* *}$ & $-0.000002^{* *}$ & -0.000004 & 0.000003 \\
& $-(3.87)$ & $(-3.32)$ & $(-1.49)$ & $(3.49)$ \\
\hline Population & $0.036^{* *}$ & 0.01 & $-0.15^{* *}$ & $0.14 * *$ \\
& $(6.07)$ & $(0.52)$ & $(-3.61)$ & $(2.45)$ \\
\hline Trade openness & 0.013 & $-0.26^{* *}$ & 0.10 & 0.03 \\
& $(0.49)$ & $(-5.25)$ & $(0.25)$ & $(0.87)$ \\
\hline Inflation & $0.002^{* * *}$ & $0.008^{* *}$ & $0.004^{* * *}$ & $0.003^{* * *}$ \\
& $(6.07)$ & $(4.74)$ & $(1.37)$ & $(3.48)$ \\
\hline Corruption & $-0.001^{* *}$ & -0.02 & $0.03^{* * *}$ & -0.002 \\
& $-(4.21)$ & $(-1.36)$ & $(1.63)$ & $(-0.58)$ \\
\hline Political stability & 0.0019 & 0.003 & $-0.0 * *$ & $(-0.002)^{* * *}$ \\
& $(0.92)$ & $(0.74)$ & $(-2.30)$ & $(-1.65)$ \\
\hline Military in Politics & $0,010^{* * *}$ & 0.007 & -0.01 & $-0.007^{* * *}$ \\
& $(1.76)$ & $(0.65)$ & $(-0.46)$ & $(-1.48)$ \\
\hline External conflicts & 0.003 & $-0.01^{* *}$ & 0.005 & 0.002 \\
& $(0.90)$ & $(-2.61)$ & $(0.75)$ & $(1.09)$ \\
\hline R-Squared & 0.94 & 0.80 & 0.83 & 0.46 \\
\hline Adjusted R-Squared & 0.93 & 0.74 & 0.77 & 0.28 \\
\hline
\end{tabular}

Note: The * indicates significant at $1 \%, * *$ indicates significant at $5 \%$ and $* * *$ indicates significant at $10 \%$.

\section{Conclusion}


The current study has a major objective to examine not only economic determinants of budget deficit but also to focus on political variables as well for South Asia and ASEAN region for 1984 to 2016. The determinants of budget deficit instability are estimated by application of panel data and time series models. For the application of panel data fixed effect and random effect models are used. Hausman test statistic is used to make a decision about the best fit model for the current study. The fixed effect model is the best fit model according to the result of Hausman test statistic.

The outcome of fixed effect explain that all variables has expected signs but effect of military in politics and external conflicts are not significant for South Asia and ASEAN region. The results of fixed effect show that inflation and real GDP per capita holds a robust effect on budget deficit. The results show that the budget deficit volatility and population growth has negative association. This result may be due to the benefits of increasing return to scale as it is possible for the government to provide more welfare projects as there is a large group of tax payers as the population growth increases. In the present analysis trade openness has shown a positive relationship with budget deficit. This may be due to the fact of rise in the import prices of the sample countries.

The current study matches the results of panel data and time series analysis and concludes that corruption and political stability are important indicators of budget deficit. According to present study institutional variables are also very important determinants of budget deficit. The outcome indicates that the budget is more stable with the higher level of political stability. The Budget deficit has more fluctuations if higher level of corruption coexists. Military in politics \& conflicts has also expected sign but their effect is not significant.

\section{Acknowledgment:}

This research is supported by grants from the National Natural Science Foundation of China (Grant No. 41701121). The authors would like to express their gratitude to Dr. Shupei Huang, Di Dong, Xiaoqi Sun, who provided valuable suggestion.

\section{References:}

Afsono, A., Agnello, A., Furceri, D. 2008. Fiscal policy responsiveness, persistence, and discretion. ECB Working paper no 954.

Alt, J. E., Lassen, D.D. 2006. Fiscal transparency, political parties, and debt in OECD countries. European Economic Review, 50(6), 1403-1439.

Alesina, A., Rodrik, D. 1994. Distributive politics and economic growth. The quarterly journal of economics, 109(2), 465-490.

Alesina, A., Tabellini, G. 1990. A positive theory of fiscal deficits and government debt. The Review of Economic Studies, 57(3), 403-414.

Alesina, A., Drazen, A. 1989. Why are Stabilizations Delayed? American Economic Review 79, 1170-1189. 
Alesina, A., Perotti, R.R. 1995. The political economy of budget deficits. IMF Staff papers, Vol. 42, 1-31.

Alesina, A., Perotti, R.R. 1996a. Income distribution, political instability, and investment. European economic review, 40(6), 1203-1228.

Alesina, A., Perotti, R.R. 1996. Budget Institutions and Budget Deficits. NBER Working Paper, 5556.

Alesina, A., Campante, F.R., Tabellini, G. 2008. Why is fiscal policy often procyclical? Journal of the european economic association, 6(5), 1006-1036.

Alesina, A., Roubini, N., Cohen, G.D. 1997. Political cycles and the macroeconomy. MIT press.

Allegret, J.P., Raymond, H. and Rharrabti, H. 2016. The Impact of the Eurozone Crisis on European Banks Stocks, Contagion or Interdependence. European Research Studies Journal, 19(1), 129-147.

Azzimonti, M., Battaglini, M., Coate, S. 2016. The costs and benefits of balanced budget rules: Lessons from a political economy model of fiscal policy. Journal of Public Economics, 136, 45-61.

Andrikopoulos, A., Loizides, I., Prodromidis, K. 2004. Fiscal policy and political business cycles in the EU. European Journal of Political Economy, 20(1), 125-152.

Barro, R.J. 1979. On the determination of the public debt. Journal of political Economy, 87(5 Part 1), 940-971.

Beck, N., Katz, J.N. 1995. What to do (and not to do) with time-series cross-section data. American political science review, 89(3), 634-647.

Boldeanu, T.F., Tache, I. 2016. The Financial System of the EU and the Capital Markets Union. European Research Studies Journal, 19(1), 60-70.

Bouton, L., Lizzeri, A., Persico, N. 2017. The Political Economy of Debt and Entitlements https://drive.google.com/.le/d/0Bz2volNj-oH7SWlxX01zbm8zTlE/view.

Butters, M.J., Coate, S. 2008. A dynamic theory of public spending, taxation, and debt. The American Economic Review, 98(1), 201-236.

Becker, J.G., Gersbach, H., Grimm, O.R. 2010. Debt-sensitive majority rules. CEPR Discussion Paper, 7860.

Chen, C., Yao, S., Hu, P., Lin, Y. 2016. Optimal government investment and public debt in an economic growth model. China Economic Review.

Cukierman, A., Meltzer, A.H. 1989. A political theory of government debt and deficits in a neo-Ricardian framework. The American Economic Review, 713-732.

De Haan, J., Sturm, J.E. 1994. Political and institutional determinants of fiscal policy in the European Community. Public Choice, 80(1-2), 157-172.

Duguleana, L., Duguleana, C. 2016. Structural Aspects of the European Union Economy. European Research Studies Journal, 19(1), 93-128.

Edin, P.A., Ohlsson, H. 1991. Political determinants of budget deficits: Coalition effects versus minority effects. European Economic Review, 35(8), 1597-1603.

Fatás, A., Mihov, I. 2003. The case for restricting fiscal policy discretion. The Quarterly Journal of Economics, 118(4), 1419-1447.

Ferejohn, J., Krehbiel, K. 1987. The budget process and the size of the budget. American Journal of Political Science, 296-320.

Franzese Jr.R.J. 2002. Electoral and partisan cycles in economic policies and outcomes. Annual Review of Political Science, 5(1), 369-421.

Fatás, A., Mihov, I. 2006. The macroeconomic effects of fiscal rules in the US states. Journal of public economics, 90(1), 101-117. 
Hallerberg, M., Strauch, R. 2002. On the Cyclicality of fiscal policy in Europe. Empirica, 29, 183-207.

Henisz, W.J. 2004. Political institutions and policy volatility. Economics \& Politics, 16(1), 127.

Jha, R. 2009b. Fiscal Policy, in A. Dutt and J. Ros (eds) International Handbook of Development Economics, London, Edward Elgar publishers, 305-318.

Glazer, A. 1989. Politics and the choice of durability. American Economic Review 79 (5), 1207-1213.

Glazer, A. 1989. Politics and the Choice of Durability. The American economic review, 79(5), 1207-1213.

Gruner, H.P. 2017. Mechanisms for the Control of Fiscal Deficits. Journal of Economic Behavior and Organization, http://dx.doi.org/10.1016/j.jebo.2017.09.019

Kontopoulos, Y., Perotti, R. 1999. Government fragmentation and fiscal policy outcomes: Evidence from OECD countries. In Fiscal institutions and fiscal performance, 81-102, University of Chicago Press.

Lane, P.R. 2003. The cyclical behaviour of fiscal policy: evidence from the OECD. Journal of Public economics, 87(12), 2661-2675.

Lizzeri, A. 1999. Budget deficits and redistributive politics. The Review of Economic Studies, 66(4), 909-928.

Leachman, L.L., Rosas, G., Lange, P., Bester, A. 2007. The political economy of budget deficits. Economics and politics, 19(3), 369-420.

Maltritz, D., Wüste, S. 2015. Determinants of budget deficits in Europe: The role and relations of fiscal rules, fiscal councils, creative accounting and the Euro. Economic Modelling, 48, 222-236.

Mink, M., De Haan, J. 2005. Has the Stability and Growth Pact Impeded Political Budget Cycles in the European Union? CESifo WP 1532 (2).

Mulas-Granados, C. 2003. The political and economic determinants of budgetary consolidation in Europe. European Political Economy Review, 1(1), 015-039.

Nordhaus, W.D. 1975. The political business cycle. The review of economic studies, 42(2), 169-190.

Persson, T. Tabellini, G. 1997. Political economy and macroeconomic policy. NBER, Working paper no 6329.

Persson, T. 2001. Do political institutions shape economic policy? NBER Working Paper, 8214.

Persson, T., Svensson, L.E. 1989. Why a stubborn conservative would run a deficit: Policy with time-inconsistent preferences. The Quarterly Journal of Economics, 104(2), 325345.

Persson, T., Tabellini, G. 1999. The size and scope of government: Comparative politics with rational politicians. European Economic Review, 43(4), 699-735.

Person, T., Tabellini, G. 2001. Political institutions and policy outcomes: what are the stylized facts? CEPR Discussion Paper no 2872.

Perotti, R., Kontopoulos, Y. 2002. Fragmented fiscal policy. Journal of Public Economics, 86(2), 191-222.

Pontoh, W. 2017. The Capital Structure: Is Debt just a Policy or Requirement? European Research Studies Journal, 20(2A), 128-139.

Rogoff, K., Sibert, A. 1988. Elections and macroeconomic policy cycles. The Review of Economic Studies, 55(1), 1-16.

Rogoff, K. 1990. Equilibrium political budget cycles. American Economic Review, 80, 2136. 
Roubini, N., Sachs, J.D. 1989a. Government spending and budget deficits in the industrial countries. Economic policy, 4(8), 99-132.

Roubini, N., Sachs, J.D. 1989b. Political and economic determinants of budget deficits in the industrial democracies. European Economic Review, 33(5), 903-933.

Song, Z., Storesletten, K., Zilibotti, F. 2012. Rotten Parents and Disciplined Children: A Politico-Economic Theory of Public Expenditure and Debt. Econometrica, 80(6), 27852803.

Shugart, M.S., Carey, J.M. 1992. Presidents and assemblies: Constitutional design and electoral dynamics. Cambridge University Press.

Sørensen, B.E., Wu, L., Yosha, O. 2001. Output fluctuations and fiscal policy: US state and local governments 1978-1994. European Economic Review, 45(7), 1271-1310.

Tabellini, G., Alesina, A. 1990. Voting on the budget deficit. American Economic Review, 80(1), 37-49.

Thalassinos, I.E., Pintea, M., Raţiu, I.P. 2015a. The Recent Financial Crisis and Its Impact on the Performance Indicators of Selected Countries during the Crisis Period: A Reply. International Journal of Economics and Business Administration, 3(1), 3-20.

Thalassinos, I.E., Stamatopoulos, D.T. and Thalassinos, E.P. 2015b. The European Sovereign Debt Crisis and the Role of Credit Swaps. Chapter book in The WSPC Handbook of Futures Markets (eds) W. T. Ziemba and A.G. Malliaris, in memory of Late Milton Miller (Nobel 1990) World Scientific Handbook in Financial Economic Series Vol. 5, Chapter 20, pp. 605-639, ISBN: 978-981-4566-91-9, (doi: 10.1142/9789814566926_0020).

Volkerink, B., De Haan, J. 2001. Fragmented government effects on fiscal policy: New evidence. Public choice, 109(3), 221-242.

Ugurlu, E., Thalassinos, E., Muratoglu, Y. 2014. Modeling Volatility in the Stock Markets using GARCH Models: European Emerging Economies and Turkey. International Journal of Economics and Business Administration, 2(3), 72-87.

Wang, S., Yang, Z., Liu, H. 2011. Impact of urban economic openness on real estate prices: Evidence from thirty-five cities in China. China Economic Review, 22(1), 42-54.

Woo, J. 2003. Economic, political, and institutional determinants of public deficits. Journal of Public Economics, 87(3), 387-426.

Woo, J. 1999. Social Polarization, Economic Development, and Fiscal Instability: Theory and Evidence. Harvard University, Unpublished working paper.

Wu, G.L., Feng, Q., Li, P. 2015. Does local governments' budget deficit push up housing prices in China? China Economic Review, 35, 183-196. 